\title{
FAKTOR-FAKTOR YANG MEMPENGARUHI KUALITAS LAPORAN KEUANGAN PEMERINTAH DAERAH
}

\author{
Rahman Pura \\ STIEM Bongaya Makassar \\ sahman_aslam@yahoo.com
}

\begin{abstract}
Abstrak
Tujuan penelitian untuk mengukur pengaruh sistem pengendalian intern, sistem informasi akuntansi dan pengawasan keuangan terhadap kualitas laporan keuangan daerah. Populasi penelitian adalah pejabat Organisasi Perangkat Daerah Kabupaten Jeneponto. Penarikan sampel menggunakan teknik sampel jenuh sehingga jumlah sampel dan sekaligus responden sebanyak 43 pejabat. Data dikumpul menggunakan teknik kuesioner dan jumlah kuesioner yang disebar ke responden sebanyak 43 kuesioner. Data diola menggunakan aplikasi SPSS dan dianalisis data menggunakan analisis regresi berganda. Hasil penelitian menunjukkan bahwa sistem pengendalian intern dan pengawasan keuangan berpengaruh positif dan signifikan terhadap kualitas laporan keuangan, sedangkan sistem informasi akuntansi berpengaruh positif tidak signifikan terhadap kualitas laporan keuangan. Penelitian ini berimplikasi pada upaya meningkatkan opini audit BPK RI atas laporan keuangan Pemerintah Daerah Kabupaten Jeneponto dari Opini Wajar Dengan Pengecualian menjadi Opini Wajar Tanpa Pengecualian. Kata kunci : Sistem Pengendalian Intern, Sistem Informasi Akuntansi, Pengawasan Keuangan, Kualitas Laporan Keuangan
\end{abstract}

\section{Abstract}

The research objective was to measure the effect of internal control systems, accounting information systems and financial controls on the quality of regional financial reports. The population of the study was the officials of the Jeneponto Regency Regional Apparatus Organization. Sampling using saturated sampling technique so that the number of samples and respondents at the same time as many as 43 officials. The data were collected using a questionnaire technique and the number of questionnaires distributed to respondents was 43 questionnaires. Data were analyzed using the SPSS application and analyzed using multiple regression analysis. The results showed that the internal control system and financial supervision had a positive and significant effect on the quality of financial reports, while the accounting information system had a positive and insignificant effect on the quality of financial reports. This research has implications for the efforts to increase the BPK RI audit opinion on the financial statements of the Jeneponto Regency Government from the Unqualified Opinion to the Unqualified Opinion.

Keywords: Internal Control System, Accounting Information System, Financial Control, Quality of Financial Statements

\section{PENDAHULUAN}

Laporan keuangan merupakan instrumen penting dalam suatu entitas, baik entitas bisnis maupun sektor publik. Karena pihak-pihak yang berkepentingan terhadap suatu perusahaan mengambil keputusan membutuhkan informasi yang disajikan dalam laporan keuangan (Pura, 2013). Dengan demikian manajemen perusahaan berkewajiban menyajikan laporan keuangan yang berkualitas, sehingga pihak-pihak yang berkepentingan tidak salah dalam mengambil suatu keputusan. Pemerintah sebagai pengemban amanah rakyat tidak terlepas dari kewajibannya untuk menyajikan laporan keuangan yang berkualitas sebagai bentuk pertangungjawabannya dalam mengelola dana masyarakat (Anwar \& Amin, 2020). Pemerintah daerah Kabupaten Jeneponto merupakan salah satu Kabupaten di Propinsi Sulawesi Selatan yang sampai saat ini masih mendapat opini Wajar Dengan Pengecualian (WDP) dari Badan Pemeriksa 
Keuangan (BPK) atas penyajikan laporan keuangan (Koran Makassar Terkini (Online), 2019). Hal ini menjadi indikasi bahwa kualitas laporan keuangan masih relatif rendah. Oleh karena itu perlu diamati, diteliti dan dianalisis faktor-faktor yang mempengaruhi penyajian laporan keuangan yang berkualitas. Sehingga dapat memberikan kontribusi bagi pemerintah daerah Kabupaten Jeneponto untuk mengambil suatu kebijakan dalam rangka memperbaiki kualitas laporan keuangan sehingga di masa yang akan datang mampu memperoleh opini audit Wajar Tanpa Pengecualian dari Badan Pemeriksa Keuangan (BPK) atas penyajian laporan keuangannya.

Pemerintah daerah harus memperhatikan nilai-nilai informasi yang disajikan dalam laporan keuangan (Pujiswara et al., 2014). Karena nilai informasi tersebut menjadi acuan pemerintah dalam menjalankan fungsi manajemen seperti perencanan dan pengendalian serta pengambilan keputusan. Hasil temuan Badan Pemeriksa Keuangan (BPK) menunjukkan bahwa pada tahun 2019 terdapat 3.094 kasus dari 397 jumlah laporan keuangan yang diaudit (BPK RI, 2019). Kemudian hasil audit BPK atas Laporan Keuangan di Pemerintah Daerah Propinsi Sulawesis Selatan Tahun Anggaran 2018 terdapat 2 daerah mendapat opini Wajar Dengan Pengecualian (WDP), satu diantaranya adalah Pemerintah Kabupaten Jeneponto (Koran Makassar Terkini (Online), 2019). Kondisi ini mengindikasikan bahwa terdapat Pemerintah Daerah menyajikan laporan keuangan yang memiliki kualitas masih rendah. Berdasarkan (Peraturan Pemerintah Nomor 71 Tahun 2010, n.d.) menjelaskan laporan keuangan yang berkualitas memiliki karaktersitik sebagai berikut; (a) relevan; (b) andal; (c) dapat dibandingkan; dan (d) dapat dipahami. Ada beberapa faktor yang berpengaruh terhadap kualitas laporan keuangan diantaranya adalah sistem pengendalian intern, sistem informasi akuntansi dan pengawasan keuangan.

Sistem pengendalian intern merupakan salah satu faktor yang mempengaruhi kualitas laporan. Penerapan sistem pengendalian intern pada lingkungan pemerintahan menjadi penting sehingga upaya untuk meningkatkan kualitas informasi laporan keuangan dapat terwujud . Menurut (Peraturan Pemerintah Nomor 60 Tahun 2008, n.d.) dan (Tuanakota, 2013) menjelaskan unsur-unsur sistem pengendalian intern meliputi ; (a). lingkungan pengendalian, (b) penilaian risiko (c) kegiatan pengendalian, (d). informasi dan komunikasi. (e).pemantauan. Salah satu tujuan penerapan sistem pengendalian intern pada organisasi pemerintah adalah untuk memberikan keyakinan atas keterandalan penyajian laporan keuangan. Dengan semakin efektif sistem pengendalian intern maka semakin berkualitas laporan kuangan. Namun, secara empiris dari beberapa hasil penelitian menunjukkan hasil yang kontradiktif. Hasil penelitian (Surastiani \& Handayani, 2015), (Lestari \& Dewi, 2020) dan (Agung \& Gayatri, 2018) menunjukkan sistem pengendalian intern berpengaruh positif signifikan terhadap kualitas laporan keuangan. Sedangkan penelitian yang dilakukan oleh (Mawuntu et al., 2020) menunjukkan pengawasan intern berpengaruh tidak signifikan terhadap kualitas laporan keuangan.

Sistem informasi akuntansi merupakan faktor lain yang turut berpengaruh terhadap kualitas laporan keuangan (Lestari \& Dewi, 2020). Semakin maju tekhnologi dan semakin berkembangnya dunia usaha maka setiap perusahaan pada umumnya mengola data dengan menggunakan sistem informasi akuntansi (Pura, 2017). Lebih lanjut (Yanti et al., 2020) menyatakan untuk menghasilkan informasi secara cepat, tepat dan akurat diperlukan sebuah sistem informasi yang mengelola data menjadi suatu informasi. Pemerintah daerah yang telah diamanahkan untuk mengelola dana 
masyarakat membutuhkan sistem informasi akuntansi untuk mengelola dana tersebut. Sistem informasi akuntansi yang berhubungan dengan pengelolaan keuangan daerah disebut dengan sistem akuntansi pemerintah daerah yaitu rangkaian kegiatan yang dimulai dari analisis transaksi sampai dengan penyajian laporan keuangan dilingkungan organisasi pemeintah daerah (Peraturan Menteri Dalam Negeri No. 64 tahun 2013, n.d.). Sistem informasi akuntansi pemerintah daerah merupakan sebuah siklus akuntansi yang memproses aktivitas keuangan pemerintah daerah untuk menghasilkan suatu informasi yang disajikan dalam laporan keuangan dan akan digunakan oleh pihak tertentu dalam mengambil suatu keputusan. Terdapat beberapa unsur sistem informasi akuntansi yakni (a). Adanya sumberdaya manusia kompeten (b). Ketersediaan peralatan yang layak. (c). adanya peraturan daerah atau keputusan kepala daerah (d). terlaksananya pemrosesan data yang akurat (e) terkendalinya data (f).terlaksananya penyediaan dan dtribusi informasi tepat waktu $(\mathrm{g})$ terpenuhinya kebutuhan informasi untuk pengambilan keputusan dalam proses perencanaan dan pengendalian operasi (Silviana \& Antoni, 2014). Semakin optimal aparatur pemerintah memanfaatkan sistem akuntansi dalam mengelola data keuangan maka informasi yang akan disajikan dalam laporan keuangan semakin berkualitas (Lestari \& Dewi, 2020). Hal ini berbeda dengan (Yanti et al., 2020) bahwa pemanfaatan sistem informasi akuntansi tidak berdampak terhadap meningkatnya kualitas laporan keuangan.

Faktor lain yang berperan penting dalam meningkatkan kualitas laporan keuangan adalah pengawasan keuangan (Yanti et al., 2020). Pengawasan keuangan daerah merupakan suatu kegiatan untuk menjamin agar pelaksanaan pengelolaan keuangan berjalan sesuai dengan peraturan yang tetapkan. Tujuan dari pengawasan keuangan negara/daerah adalah : (a) untuk menjaga agar anggaran yang disusun benar-benar dapat dijalankan, (b) untuk menjaga agar kegiatan penerimaan dan pembelanjaan pengeluaran negara/daerah sesuai dengan anggaran yang telah digariskan dan (c) untuk menjaga agar pelaksanaan APBN/APBD benar-benar dapat dipertanggungjawabkan (Ulum, 2008). Semakin baik pengawasan atas pengelolan keuangan negara/daerah semakin meningkat kualitas informasi dalam penyajian laporan keuangan. Hal ini sesuai dengan hasil penelitian yang dilakukan oleh (Rifandi, 2018), (Patongai et al., 2018) dan (Yanti et al., 2020) bahwa pengawasan keuangan berpengaruh dalam meningkatkan kualitas laporan keuangan.

Penelitan ini bertujuan untuk mengukur pengaruh sistem pengendalian intern, sistem informasi akuntansi dan pengawasan keuangan terhadap kualitas laporan keuangan pemerintah pada Pemerintah Daerah Kabupaten Jeneponto. Hasil penelitian disatu sisi diharapkan memberikan kontribusi dalam pengembangan ilmu akutansi sektor publik, disisi yang lain dapat menjadi bahan pertimbangan pemerintah, khususnya pemerintah Kabupaten Jeneponto untuk mengambil suatu kebijakan dalam rangka memperbaiki kualitas laporan keuangan sehingga di masa yang akan datang mampu memperoleh opini audit Wajar Tanpa Pengecualian dari Badan Pemeriksa Keuangan.

\section{METODE PENELITIAN Jenis Penelitian}

Penelitian ini merupakan penelitian dengan pendekatan kuantitatif dan dari jenisnya merupakan penelitian replikatif, yakni melakukan pengujian ulang terhadap hasil-hasil penelitian sebelumnya pada lokasi atau kondisi yang berbeda (Ferdinand, 
2011). Dan metode penelitiannya merupakan penelitian deskriptif yaitu penelitian dengan metode pengumpulan data pada populasi dan sampel yang ditentukan peneliti (Riduwan, 2008).

\section{Prosedur}

Penelitian ini diawali dengan ada Fenomena tentang opini BPK RI atas laporan keuangan Kabupaten Jeneponto dan beberapa hasil penetian yang kontradiktif yang terkait dengan variabel penelitian. Dari fenomena dan kontradiksi hasil penelitian sebelumnya kemudian ditemukan dan dirumuskan masalah penelitian. Selanjutnya dilakukan kajian pustaka secara teoritis dan empiris yang relevan dengan masalah penelitian. Kemudian dirumuskan hipotesis. Kemudian dilakukan pengumpulan data, pengujian data dan analisis data untuk menguji hipotesis dan ditarik kesimpulan penelitian.

\section{Instrumen dan Operasional Variabel}

Instrumen penelitian berupa kuesioner yang disusun berdasarkan indikator variabel. Operasional variabel dapat dijelaskan pada tabel berikut ini :

Tabel 1 : Operasional variabel

\begin{tabular}{|c|c|c|c|}
\hline No & Variabel & Indikator & $\begin{array}{c}\text { Skala } \\
\text { Pengukuran }\end{array}$ \\
\hline 1 & $\begin{array}{l}\text { Kualitas Laporan } \\
\text { Keuangan }(Y)\end{array}$ & $\begin{array}{l}\text { 1. Relevan } \\
\text { 2. Andal } \\
\text { 3. Dapat dibandingkan, dan } \\
\text { 4. Dapat dipahami. } \\
\text { (Sumber : PP } 71 \text { Tahun 2010) }\end{array}$ & $\begin{array}{l}\text { Skala } \\
\text { ordinal }\end{array}$ \\
\hline 2 & $\begin{array}{l}\text { Sistem Pengendalian } \\
\text { Intern } \\
\text { (X1) }\end{array}$ & $\begin{array}{l}\text { 1. Lingkungan pengendalian } \\
\text { 2. Penilaian risiko } \\
\text { 3. Kegiatan pengendalian } \\
\text { 4. Informasi dan komunikasi dan } \\
\text { 5. Pemantauan. } \\
\text { (Sumber : PP No.60 Tahun } 2010 \\
\text { dan Tuanakota, 2013) }\end{array}$ & $\begin{array}{l}\text { Skala } \\
\text { ordinal }\end{array}$ \\
\hline 3. & $\begin{array}{l}\text { Sistem } \\
\text { Akuntansi } \\
\text { (X2) }\end{array}$ & $\begin{array}{l}\text { 1. Prosedur } \\
\text { 2. Penyelenggara, } \\
\text { 3. Sarana dan prasarana } \\
\text { 4. Sumber daya manusia. } \\
\text { (Sumber : Peraturan Menteri } \\
\text { Dalam Negeri Nomor } 64 \text { Tahun } \\
\text { 2013) }\end{array}$ & $\begin{array}{l}\text { Skala } \\
\text { ordinal }\end{array}$ \\
\hline 4 & $\begin{array}{l}\text { Pengawasan } \\
\text { Keuangan } \\
\text { (X3) }\end{array}$ & $\begin{array}{l}\text { 1. } \begin{array}{l}\text { Menjamin kepastian implementasi } \\
\text { anggaran }\end{array} \\
\text { dilaksanakan } \\
\text { 2. Menar-benar } \\
\text { penjaga agar } \\
\text { penimaan dan pembelanjaan }\end{array}$ & \\
\hline
\end{tabular}




\begin{tabular}{llc}
\hline No $\quad$ Variabel & \multicolumn{1}{c}{ Indikator } & $\begin{array}{c}\text { Skala } \\
\text { Pengukuran }\end{array}$ \\
\hline & & \\
& pengeluaran negara/daerah sesuai & \\
& dengan anggaran yang telah & Skala \\
& digariskan dan & \\
& & \\
3. & Menjaga agar pelaksanaan \\
& APBN/APBD benar-benar dapat & \\
& dipertanggungjawabkan. \\
& (Sumber : Keputusan Presiden & \\
& Nomor 74 Tahun 2001 dalam \\
& Ulum, 2008) \\
\hline
\end{tabular}

Indikator variabel tersebut untuk kemudian dirancang instrument penelitian sebagai alat untuk mengumpulkan data. Instrumen penelitian disusun dengan menggunakan type skala likert, dengan skala pengukuran 5, 4, 3, 2, 1 .

\section{Teknik Analisis Data}

Untuk menguji pengaruh sistem pengendalian intern, sistem informasi akuntansi dan pengawasan keuangan terhadap kualitas laporan keuangan pada Pemerintah daerah Kabupaten Jeneonto menggunakan teknik Analisis Regresi Berganda dengan persamaan regresi :

Dimana :

$$
Y=\alpha+\beta_{1} X_{1}+\beta_{2} X_{2}+\beta_{3} X_{3}+\varepsilon
$$

$\begin{array}{lll}\mathrm{Y} & = & \text { Kualitas laporan keuangan } \\ \mathrm{X}_{1} & = & \text { Sistem pengendalian intern } \\ \mathrm{X}_{2} & = & \text { Sistem informasi akuntansi } \\ \mathrm{X}_{3} & = & \text { Pengawasan keuangan } \\ \alpha & = & \text { Koefisien intercept (konstanta), yaitu nilai } \mathrm{Y} \text { jika nilai } \\ & & \text { seluruh variabel lain adalah nol } \\ \beta_{1-3} & = & \text { Kooefisien regresi } \\ \varepsilon & = & \text { error term (residual) }\end{array}$

\section{HASIL DAN PEMBAHASAN}

Hasil

\section{Hasil Uji Validitas dan Releabilitas}

Hasil penelitian yang valid bila terdapat kesamaan antara data yang terkumpul dengan data yang sesungguhnya terjadi pada objek yang diteliti, sedangkan hasil penelitian yang relealibel bila terdapat kesamaan data dalam waktu yang berbeda (Sugiyono, 2016)

Uji validasi data dalam penelitian ini dilakukan dengan teknis analisis item, yaitu dengan cara mengkorelasikan skor tiap-tiap item pertanyaan dengan total skor untuk masing-masing variabel. teknik korelasi yang digunakan dalam melakukan uji validasi adalah Pearson Product Moment (Riduwan, 2008). Kriteria yang digunakan untuk menyatakan suatu instrumen dianggap valid atau layak digunakan dalam pengujian hipotesis apabila koofisien korelasi lebih besar atau sama dengan 0,30. Hasil uji validitas data dapat dilihat dari tabel berikut ini : 
Tabel 2 : Hasil Uji Validitas Data

\begin{tabular}{lccccc}
\hline \multirow{2}{*}{ Variabel } & \multicolumn{5}{c}{ Nilai r Hitung Untuk Setiap Item Pertanyaan } \\
\cline { 2 - 6 } & No.1 & No.2 & No.3 & No.4 & No.5 \\
\hline X1 & 0,74 & 0,84 & 0,88 & 0,86 & 0,77 \\
X2 & 0,83 & 0,84 & 0,87 & 0,69 & - \\
X3 & 0,84 & 0,87 & 0,69 & - & - \\
Y & 0,62 & 0,57 & 0,80 & 0,77 & - \\
\hline r Kritis & 0,30 & 0,30 & 0,30 & 0,30 & 0,30 \\
\hline Keputusan & Valid & Valid & Valid & Valid & Valid \\
\hline
\end{tabular}

Sumber : Data diolah menggunakan SPSS 24 (2020)

Berdasarkan data pada tabel 2 tersebut menunjukkan bahwa semua item pertanyaan dari semua variabel penelitian memiliki nilai korelasi ( $\mathrm{r}$ hitung) lebih besar dari nilai $\mathrm{r}$ kritis $(0,30)$. Dengan demikian semua item pertanyaan dikatakan valid. Artinya bahwa terdapat kesamaan data yang terkumpul dengan data yang sesungguhnya.

Kemudian uji reliabilitas pada penelitian ini dilakukan dengan menggunakan metode Alpha.

Kriteria yang digunakan untuk menyatakan suatu instrumen dikatakan reliabel jika memberikan nilai Cronbach Alpha ( $\alpha$ ) lebih besar daripada 0,60 (Nunnally, 1967) dalam dalam (Ghozali, 2005). Hasil perhitungan releabilitas data dapat dilihat dalam tabel berikut ini :

\section{Tabel 3 : Hasil Uji Releabilitas Data}

\begin{tabular}{|c|c|c|c|}
\hline Variabel & Nilai Alpha & Nilai Kritis & Keputusan \\
\hline $\mathrm{X} 1$ & 0,88 & 0,60 & Relealibel \\
\hline $\mathrm{X} 2$ & 0,81 & 0,60 & Relealibel \\
\hline $\mathrm{X} 3$ & 0,71 & 0,60 & Relealibel \\
\hline Y & 0,61 & 0,60 & Relealibel \\
\hline
\end{tabular}

Sumber : Data diolah menggunakan SPSS 24 (2020)

Berdasarkan hasil pengujian tersebut menunjukkan bahwa nilai alpha dari setiap variabel lebih besar dari nilai kritis $(0,60)$ sehingga data ini dikatakan relealibel. Dalam artian bahwa terdapat kesamaan data dalam waktu yang berbeda.

\section{Hasil Uji Asumsi Klasik}

Suatu penelitian dengan menggunakan analisis regresi harus memenuhi syarat uji asumsi klasik, oleh karena ini sebelum data dianalisis dengan regresi data tersebut diuji terlebih dahulu melalui uji asumsi klasik. Adapun hasil pengujian asumsi klasik dalam penelitian ini adalah sebagai berikut :

\section{a. Uji Normalitas}

Data yang akan dianalisis dengan menggunakan analisis regresi harus berdistribusi normal, pengujian normalitas data dalam penelitian ini menggunakan analisis statistik, yaitu dengan menggunakan uji Kolmogorov-Smirnov (KS). Hasil uji normalitas dengan menggunakan uji KS dapat dilihat dari tabel berikut ini : 
Tabel 4 : Uji Normalitas

One-Sample Kolmogorov-Smirnov Test

\begin{tabular}{lc}
\hline & $\begin{array}{c}\text { Unstandardized } \\
\text { Predicted Value }\end{array}$ \\
\hline $\mathrm{N}$ & 30 \\
Test Statistic & 0,091 \\
Asymp. Sig. (2-tailed) & 0,200 \\
\hline
\end{tabular}

Sumber : Data diolah menggunakan SPSS 24 (2020)

Berdasarkan tabel di atas menunjukkan nilai signifikasi yaitu sebesar 0,200. Nilai signifikasi tersebut lebih besar dari nilai 0,050 yang dapat dikatakan bahwa data yang digunakan dalam penelitian ini berdistribusi normal, sehingga asumsi untuk pengujian normalitas data terpenuhi dan analisis data dapat dilanjutkan

\section{b. Uji Multikolineritas}

Asumsi multikolinearitas adalah asumsi yang menggambar tidak ada hubungan kolinearitas antara variabel independen yang diteliti. Untuk menguji multikolinearitas menggunakan analisis Tolerance dan VIF. Hasil ujinya dapat dilihat dalam tabel berikut ini :

Tabel 5 : Uji Multikolineritas

\begin{tabular}{lcc}
\hline & Model & \multicolumn{2}{c}{ Collinearitas Statistic } \\
\cline { 2 - 3 } & \multicolumn{2}{c}{ Tolerance } \\
\hline \\
X1 & 0,740 & VIF \\
X2 & 0,405 & 1,351 \\
X3 & 0,485 & 2,467 \\
& & 2,062 \\
\hline
\end{tabular}

Sumber : Data diolah menggunakan SPSS 24 (2020)

Berdasarkan table diatas menunjukkan nilai tolerance dan nilai VIF pada masingmasing variable. Nilai tolerance pada masing-masing variabel tersebut lebih besar dari nilai 0,10 dan nilai VIF pada masing-masing variable lebih kecil dari nilai 10,0 yang dapat dikatakan bahwa tidak terdapat masalah. Artinya tidak hubungan antara kolinearitas antara variabel independen yang diteliti sehingga asumsi kolonieritas dalam penelitian ini terpenuhi.

\section{Hasil Uji Analisis Determinasi $\left(\boldsymbol{R}^{2}\right)$}

Analilis determinasi digunakan untuk mengetahui berapa besar variasi perubahan variabel independen terhadap variabel dependen. Dengan kata lain untuk mengukur berapa besar konstribusi variabel independen dalam mempengaruhi variabel dependen. Untuk mengukur besarnya kontribusi pengaruh variabel sistem pengendalian intern, sistem infromasi akuntansi dan pengawasan keuangan terhadap kualitas laporan keuangan pada Pemerintah daerah Kabupaten Jeneponto dapat lihat dari nilai $R$ Square, seperti terlihat dari tabel berukut ini: 
Tabel 6 : Analisis Determinasi

\begin{tabular}{cccc}
\hline Model & $\mathrm{R}$ & R Square & $\begin{array}{c}\text { Adjusted } \\
\text { R Square }\end{array}$ \\
\hline 1 & 0,740 & 0,548 & 0,513 \\
\hline
\end{tabular}

Sumber : Data diolah menggunakan SPSS 24 (2020)

Berdasarkan data pada tabel diatas menunjukkan nilai $\mathrm{R}$ square yaitu sebesar 0,548 . Hal ini berarti bahwa varibel sistem pengendalian intern $\left(\mathrm{X}_{1}\right)$, sistem infromasi akuntansi $\left(\mathrm{X}_{2}\right)$, dan pengawasan keuangan $\left(\mathrm{X}_{3}\right)$ secara bersama-sama mempengaruhi variabel kualitas laporan keuangan(Y) sebesar 54,8\%. Sedangkan sebesar 45,2\% (100\% - 54,8\%) dipengaruhi oleh variabel lain yang tidak dimasukkan dalam penelitian ini. Dengan kata lain kontribusi varibel sistem pengendalian intern $\left(\mathrm{X}_{1}\right)$, sistem infromasi akuntansi $\left(\mathrm{X}_{2}\right)$, dan pengawasan keuangan $\left(\mathrm{X}_{3}\right)$ mempengaruhi variabel kualitas laporan keuangan(Y) pada Pemerintah Daerah Kabupaten Jeneponto sebesar 54,8\%.

\section{Hasil Uji Koofisien Regreasi dan Persamaan Regresi}

Nilai koofisien regresi pengaruh sistem pengendalian intern, sistem informasi akuntansi dan pengawasan keuangan terhadap kualitas laporan keuangan dapat dilihat pada tabel koofisien berikut ini :

Tebel 7: Hasil Perhitungan Koofisien Regresi

\begin{tabular}{lrrrr}
\hline Uraian & $\begin{array}{c}\text { Koofisien } \\
\text { regresi }\end{array}$ & $\begin{array}{c}\text { Standar } \\
\text { Error }\end{array}$ & t hitung & probabiliy \\
\hline Konstanta & 4.355 & 2.003 & 2.174 & .036 \\
X1 & .271 & .088 & 3.078 & .004 \\
X2 & .168 & .142 & 1.185 & .243 \\
X3 & .396 & .189 & 2.092 & .043 \\
\hline
\end{tabular}

Sumber : Data diolah menggunakan SPSS 24 (2020)

Bentuk persamaan regresi dari pengolahan data terseb sebagai berikut :

$$
\mathrm{Y}=4.356+0,271 \mathrm{X}_{1}+0,168 \mathrm{X}_{2}+0,396 \mathrm{X}_{3}+\varepsilon
$$

Model tersebut menjelaskan nailai koofisien variabel sistem pengendalian intern bertanda positif 0,271 berarti apabila sistem pengendalian intern meningkat $1 \%$, maka kualitas laporan keuangan akan meningkat $0,271 \%$ pada saat variabel independen lainnya tidak berubah, variabel sistem informasi akuntansi memiliki koefisien regresi bertanda postif 0,168 yang berarti apabila sistem informasi akuntansi meningkat $1 \%$, maka kualitas laporan keuangan meningkat $0,168 \%$ pada saat variabel independen lainnya tidak berubah, variabel pengawasan keuangan memiliki koefisien regresi bertanda positif 0,396 berarti apabila pengawasan keuangan meningkat $1 \%$, maka kualitas laporan keuangan akan meningkat $0,396 \%$ pada saat variabel bebas lainnya 
tidak berubah. Dan jika sistem pengendalian intern, sistem informasi akuntansi dan pengawasan keuangan tidak mengalami perubahan maka kualitas laporan keuangan memiliki nilai $4,356 \%$.

\section{Pembahasan}

\section{Analisis Sistem Pengendalian Intern Terhadap Kualitas Laporan Keuangan}

Analisis data menunjukkan sistem pengendalian intern berpengaruh positif dan signifikan terhadap kualitas laporan keuangan. Dengan demikian hipotesis yang diajukan dalam penelitian ini diterima (Ha diterima). Hal ini berarti semakin efektif penerapan sistem pengendalian intern maka semakin meningkat kualitas laporan keuangan. Untuk meningkatkan kepercayaan dan keyakinan masyarakat terhadap suatu perusahaan atau organiasasi maka manajemen perusahaan perlu menyajikan informasi yang berkualitas pada laporan keuangan, oleh karena itu salah satu upaya yang dilakukan adalah dengan mengefektifkan penerapan sistem pengendalian intern (Surastiani \& Handayani, 2015). Lebih lanjut dijelaskan dalam (Peraturan Pemerintah Nomor 60 Tahun 2008, n.d.) bahwa tujuan sistem pengendalian intern adalah untuk meningkatkan keandalan penyajian laporan keuangan. Pada dasarnya pemerintah daerah telah menerapkan sistem pengendalian intern dalam mengelola keuangan daerah.

Sistem pengendalian intern sangat berperan penting dalam menghasilkan laporan keuangan yang berkualitas sehingga menjadi suatu keharusan bagi pemerintah daerah untuk lebih efektif dalam menerapkannya. Semakin efektif penerapan sistem pengendalian intern maka semakin berkualitas penyajian informasi laporan keuangan. Hasil penelitian ini mendukung penelitian yang telah dilakukan oleh (Surastiani \& Handayani, 2015), (Anwar \& Amin, 2020) dan (Lestari \& Dewi, 2020) yakni sistem pengendalian intern berpengaruh signifikan terhadap kualitas laporan keuangan pemerintah daerah.

\section{Analisis Sistem Informasi Akuntansi Terhadap Kualitas Laporan Keuangan}

Hasil analisis data tersebut menunjukan sistem informasi akuntansi berpengaruh positif tidak tidak signifikan terhadap kualitas laporan keuangan. Dengan demikian hipotesis yang diajukan dalam penelitian ini ditolak (Ha ditolak). Hal ini bermakna sistem informasi akuntansi keuangan tidak memberikan pengaruh terhadap kualitas laporan keuangan. Sistem informasi akuntansi pada dasarnya dapat meminimalisir terjadinya kesalahan dalam pencatatan dan pengolahan data serta berdampak terhadap kualitas laporan keuangan, namun, hal itu saja tidak cukup karena sistem informasi akuntansi juga membutuhkan unsur ketersediaan teknologi yang cukup, kompetensi sumber daya manusia yang handal dan prosedur sistem yang efektif. Unsur-unsur tersebut harus teringrasi yang merupakan satu kesatuan dalam menjalankan sistem informasi akuntansi. Apabila salah satu unsur tidak berjalan secara efektif maka implementasi sistem informasi akan terganggu. Faktor utama yang menjadi kendala yang dialami pemerintah daerah dalam menerapkan sistem informasi akuntansi adalah ketersediaan sarana dan prasarana berupa teknologi informasi dan aplikasi pendukung lainnya dalam menerapkan sistem informasi akuntansi. Faktor penghambat lainnya adalah sumber daya manusia yang menjalankan sistem informasi akuntansi. Kualifikasi pendidikan pegawai yang mengaplikasikan sistem informasi akuntansi tersebut pada umumnya tidak sesuai dengan bidangnya. Paling tidak pegawai yang menjalankan 
sistem informasi akuntansi harus memahami teknik-teknik akuntansi dan terampil dalam mengaplikasikan komputer.

Menurut (Pura, 2017) mengatakan semakin berkembangnya teknologi dan berkembangnya dunia usaha maka pengelolaan data menjadi informasi telah banyak diterapkan sistem informasi akuntansi. Lebih lanjut (Yanti et al., 2020) menyatakan untuk menghasilkan informasi yang cepat, tepat dan akurat perlu menerapkan sistem informasi akuntansi. Kemudian (Lestari \& Dewi, 2020) mengatakan untuk memperoleh informasi yang cepat dan akurat, pemerintah perlu memanfaatkan teknologi infromasi, karena teknologi sebagai alat untuk mempermudah dan memperlancar implementasi sistem informasi. Hal ini kemudian berdampak pada meningkatnya kualitas laporan keuangan.

Semakin optimal pemanfaatan sistem informasi akuntansi dalam mengelola data keuangan maka dapat meningkatkan kualitas laporan keuangan. Dalam mengelola keuangan daerah telah diterapkan aplikasi Sistem Akuntansi Keuangan Daerah. Oleh karena itu, agar aplikasi keuangan daerah tersebut dapat dimanfaatkan secara baik dijalankan secara efektif dalam menghasilkan laporan keuangan yang berkualitas maka pemerintah daerah perlu menyediakan teknologi informasi yang berbasis komputersasi, dan ketersediaan sumber daya manusia yang ahli dan terampil dalam menjalankan Sistem Akuntansi Keuangan Daerah tersebut. Hasil penelitian ini selaras dengan hasil penelitian (Yanti et al., 2020) yakni sistem informasi akuntansi tidak berpengaruh signfikan terhadap kualitas laporan keuangan.

\section{Analisis Pengawasan Keuangan Terhadap Kualitas Laporan Keuangan}

Hasil analisis data menunjukkan bahwa pengawasan keuangan berpengaruh positif signifikan terhadap kualitas lapaoran keuangan. Dengan demikian hipotesis yang diajukan dalam penelitian ini diterima (Ha diterima). Hasil penelitian ini dapat dijelaskan semakin optimal pengawasan dalam pengelolaan keuangan daerah maka hal ini akan berdampak terhadap peningkatan kualitas laporan keuangan. Peran pengawasan memberikan suatu kepercayaan bahwa informasi yang disajikan dalam laporan keuangan benar-benar menunjukkan informasi yang berkualitas. Untuk meningkatkan dan menjaga kepercayaan masyarakat terhadap kinerja pemerintah maka salah satu cara yang dilakukan adalah dengan menciptakan suatu sistem pengawasan yang efektif, baik pengawasan internal maupun pengawasan eksternal (Patongai et al., 2018). Hasil penelitian mendukung penelitian yang dilakukan oleh (Pujiswara et al., 2014), (Patongai et al., 2018) dan (Rifandi, 2018).

\section{KESIMPULAN}

Berdasarkan hasil penelitian dan pembahasan yang telah diuraikan maka hasil penelitian ini dapat disimpulkan bahwa :

1. Sistem pengendalian intern berpengaruh positif dan signifikan terhadap kualitas laporan keuangan

2. Sistem informasi akuntansi berpengaruh positif tidak signifikan terhadap kualitas laporan keuangan.

3. Pengawasan keuangan berpengaruh positif dan signifikan terhadap kualitas laporan keuangan. 


\section{Implikasi Penelitian}

Penelitian ini berimplikasi pada upaya meningkatkan opini audit BPK RI atas laporan keuangan Pemerintah Daerah Kabupaten Jeneponto dari Opini Wajar Dengan Pengecualian menjadi Opini Wajar Tanpa Pengecualian

\section{REFERENSI}

Anwar, A., \& Amin, A. (2020). Dimensi Karakteristik Laporan Keuangan Pemerintah. e-Jurnal Akuntansi. https://doi.org/10.33369/j.akuntansi.10.3.223-230, 10(3).

Agung, T. M., \& Gayatri. (2018). Analisis Faktor-Faktor yang Mempengaruhi Kualitas Laporan Keuangan Pemerintah Daerah Kabupaten Karangasem. E-Jurnal Akuntansi, 23, 1253-1276. https://doi.org/10.24843/eja.2018.v23.i02.p17

BPK RI. (2019). Ikhtisar Hasil Pemeriksaan Semester II Tahun 2019.

Ferdinand, A. (2011). Metode Penelitian Manajemen. Badan Penerbit Universitas Diponegoro.

Ghozali, I. (2005). Aplikasi Analisis Multivariate Dengan Program SPSS. BP Universitas Diponegoro.

Koran Makassar Terkini (Online). (2019). Ini Alasan BPK Berikan Pemkab Jeneponto Opini WDP. https://makassar.terkini.id/alasan-bpk-berikan-pemkab-jenepontoopini-wdp

Lestari, N. L. W. T., \& Dewi, N. N. S. R. T. (2020). Pengaruh Pemahaman Akuntansi, Pemanfaatan Sistem Informasi Akuntansi Dan Sistem Pengendalian Intern Terhadap Kualitas Laporan Keuangan. KRISNA: Kumpulan Riset Akuntansi, 11(2), 170-178. https://doi.org/10.22225/kr.11.2.1435.170-178

Mawuntu, N. S., Manossoh, H., \& Afandi, D. (2020). Pengaruh Kepatuhan Dan Pengawasan Terhadap Kualitas Laporan Keuangan Pemerintah Daerah (Studi Empiris Pada Pemerintah Kabupaten Minahasa Utara). Going Concern: Jurnal Riset Akuntansi, 15(2), 260. https://doi.org/10.32400/gc.15.2.28230.2020

Patongai, W., Palampanga, A., \& Yusnita, N. (2018). Pengaruh kualitas data input, tingkat pemahaman dan tingkat pengawasan terhadap kualitas laporan keuangan (Studi pada SKPD di Kabupaten Tolitoli). E Jurnal Katalogis, 6(2), 86-97.

Peraturan Menteri Dalam Negeri No. 64 tahun 2013. (n.d.). Tentang Penerapan Standar Akuntansi Pemerintahan Berbasis Akrual Pada Pemerintah Daerah.

Peraturan Pemerintah Nomor 60 Tahun 2008. (n.d.). Tentang Sistem Pengendalian Intern Pemerintah.

Peraturan Pemerintah Nomor 71 Tahun 2010. (n.d.). Tentang Standar Akuntansi Pemerintah. 
Pujiswara, I. B., Herawati, N. T., \& Sinarwati, N. K. (2014). Pengaruh Pemanfaatan Sistem Informasi Akuntansi Keuangan Daerah Dan Pengawasan Keuangan Daerah Terhadap Nilai Informasi Pelaporan Keuangan Dan Akuntabilitas Pemerintah Daerah (Studi pada Satuan Kerja Perangkat Daerah di Kabupaten Klungkung). Journal S1 Ak Universitas Pendidikan Ganesha Jurusan Akuntansi Program S1, 2(1).

Pura, R. (2013). Pengantar Akuntansi I : Pendekatan Siklus Akuntansi. PT Erlangga.

Pura, R. (2017). Effects of Auditor Competence, Information Technology, Accounting Information Systems and Organizational Commitment on Auditors' Performance at The State Audit Agency, In South Sulawesi. Scientific Research Journal, V(X), $16-22$.

Riduwan. (2008). Metode dan Teknik Menyusun Tesis. Alfabeta.

Rifandi, M. (2018). Pengaruh Teknologi Informasi Dan Pengawasan Keuangan Terhadap Nilai Informasi Laporan Keuangan Pemerintah Daerah. Relasi : Jurnal Ekonomi, 14(2), 48-61. https://doi.org/10.31967/relasi.v14i2.263

Silviana, \& Antoni, E. (2014). Pengaruh Penerapan Sistem Informasi Akuntansi Terhadap Kualitas Laporan Keuangan Pemerintah Daerah Survey Pada Pemerintah Kabupaten Di Seluruh Jawa Barat. PROVITA, 6(1), 24-28.

Sugiyono. (2016). Metode Penelitian Manajemen (Bandung). Alfabeta.

Surastiani, D. P., \& Handayani, B. D. (2015). Analisis Faktor-Faktor yang Mempengaruhi Kualitas Laporan Keungan Pemerintah Daerah. Jurnal Dinamika Akuntansi, 7(2), 139-149.

Tuanakota, T. (2013). Audit Berbasis ISA (International Standards on Auditing,. Salemba Empat.

Ulum, I. (2008). Akuntansi Sektor Publik. UMM Press.

Yanti, N. S., Made, A., \& Setiyowati, S. W. (2020). Pengaruh Penerapan Standar Akuntansi Pemerintah, Pemanfaatan Sistem Informasi Akuntansi Dan Pengawasan Keuangan Terhadap Kualitas Laporan Keuangan Pemerintah Daerah. Jurnal Riset Mahasiswa Akuntansi, 8(1), 1-8. https://doi.org/10.21067/jrma.v8i1.4455 